\title{
Household's Willingness to Pay for Improved Solid Waste Management in Gulelle Sub City, Addis Ababa
}

\author{
Galgalo Dika*, Aga Nemie, Endalkachew Birhane \\ Centre for Environment and Development, College of Development Studies, Addis Ababa University, Ethiopia
}

Copyright $\mathrm{C} 2019$ by authors, all rights reserved. Authors agree that this article remains permanently open access under the terms of the Creative Commons Attribution License 4.0 International License

\begin{abstract}
This study was conducted to assess households willingness to pay (WTP) for improved solid waste management (SWM). Contingent valuation method (CVM) was employed to elicit household's WTP for the proposed improvement in solid waste management service. The data from CVM survey was analyzed by using logistic regression model. The results of the study revealed that largest proportion of households had awareness of inappropriate disposal of wastes and its problems and that they were $(78 \%)$ ready to pay for the wastes they generate. Furthermore, we found that significant number of the respondents $(76 \%)$ were willing to supports proposed improvement in residential solid waste management. Mean monthly willingness to pay is 21 Ethiopian Birr (ETB) with a minimum of 5 ETB and the maximum of $100 \mathrm{ETB}$, while the rest of the respondents were not willing to contribute. The results of logit regression analysis showed that sex and household size were statistically significant at 5\% and $1 \%$ respectively. Therefore, the concerned body (municipality, NGO or other voluntary group) should take their part in raising the awareness and perceptions of households on waste management and thus, to improve their willingness to pay for improved SWM.
\end{abstract}

Keywords Solid Waste, Contingent Valuation, Willingness to Pay, Households' Perceptions, Gulelle Sub City, Addis Ababa

\section{Introduction}

Waste management issues are coming to the forefront of the global environmental agenda at an increasing frequency, as population and consumption growth result in increasing quantities of waste (1). While cities are generating an ever-increasing volume of waste, the effectiveness of their solid waste collection and disposal systems are declining (2). For instance, in urban centers throughout African regions, less than half of the solid waste produced is collected, and 95 percent of that amount is either indiscriminately thrown away at various dumping sites on the periphery of urban centers, or at a number of so-called temporary sites, typically empty lots scattered throughout the city.

Solid waste is one of the major problem human being continued to face for different reasons. Firstly, it is adversely affecting the environment (1). Secondly, it has become the major cause of health problem in urban areas (3). Finally, it is causing loss of human life in some countries by a sudden fall of the accumulated waste on people. The typical example here is the sudden fall of the accumulated solid waste on the people of Qoshe area in Addis Ababa that caused the loss of people life and property. Thus, Collecting and managing solid and human waste is an important challenge for countries across the World (4). Sound management of waste is therefore necessary to avoid substantial adverse human, health and environmental effects that are associated with poor waste management.

The Ethiopian government had proclaimed the solid waste management proclamation in 2007 and encouraged community participation. Despite this, waste management continue to be one of the major challenges that many urban centers of the country including Addis Ababa faces. Addis Ababa city started its solid waste management some three decades back (2). The solid waste collection and management is coordinated by the Addis Ababa city administration and their efforts are assisted with the contribution of fees collected from all registered Addis Ababa Households and businesses outlets (5). It is carried out by so-called pre-collectors (micro-enterprises) that collect unsorted waste from households, businesses and public spaces.

About $20 \%$ to $30 \%$ of the waste generated in Addis Ababa remained uncollected and made the city environment aesthetically unpleasant and affected the city's public health. The household collects the solid waste generated in their home in nylon bag in their compound and transfer it to the pre-collectors. While there is currently no source-separation or systematic sorting of household waste, the collection micro-enterprises typically sort out 
valuable waste fractions at their own initiative (5). This is done mainly after transferring the waste to the dumpsite.

Therefore, it is clear from the literature that the existing condition of waste management in Addis Ababa is not to the expected level despite there exists a number of efforts to tackle problem related to solid waste management. This is actually the factor that initiated the researchers to carry out their study on solid waste management. Hence, the purpose of this paper is to assess the current situation of solid waste and households' willingness to pay for an improved solid waste management in Gulele Sub-city, Addis Ababa.

These day's waste management problems have gained the global concerns because of its serious threat on human and environment. In Addis Ababa city, the main bottlenecks associated with waste management are high and varied amount of waste generate from households; disposal on streets, in ditches and rivers; low perception and attitude of community on waste management; inefficient services rendered by municipality; low willingness of households and lack of appropriate waste disposal site. These problems are observable in Woreda ${ }^{1} 3$ of Gulelle sub-city. The problems have been worsened and even disposing over street seems right as even cart driven waste collectors are pilling them up on the street, so that it can be transported to the other place latter. In such area, it is pungent to pass nearby, as wastes stay pilled over there for many period. So far, many studies had been conducted in the different sub-city of the city. For instance, have tried to assess household's willingness to pay for improved solid waste management. On the other hand, have assessed the challenges and opportunities of solid waste management in Bole and Akaki-Kaliti sub-city. Nontheless, there is lack of sufficcient evidence on the study particularty undertaken in woreda 3 of Gullle sub-city. Thus, it has become highly important to assess the conditions of solid wastes; peoples perceptions and atitudes on solid waste managemet and households willigness to pay for improved solid waste management in this area. Thus, the main purpose of this study was to assess household's willingness-to-pay for improved solid waste management.

\section{Methods and Materials}

\subsection{The Study Area}

The study was conducted in Gullele sub-city, Addis Ababa, Ethiopia. Gulele sub-city is located in the northern suburb of the city near mountain Entoto and it shares boundary with the districts of Kolfe Keranio, Addis Ketema, Arada and Yeka sub-cities. Gulele has ten administrative districts with total area of $30.18 \mathrm{~km} 2$.

1 Woreda is the next highest-level local administrative unit

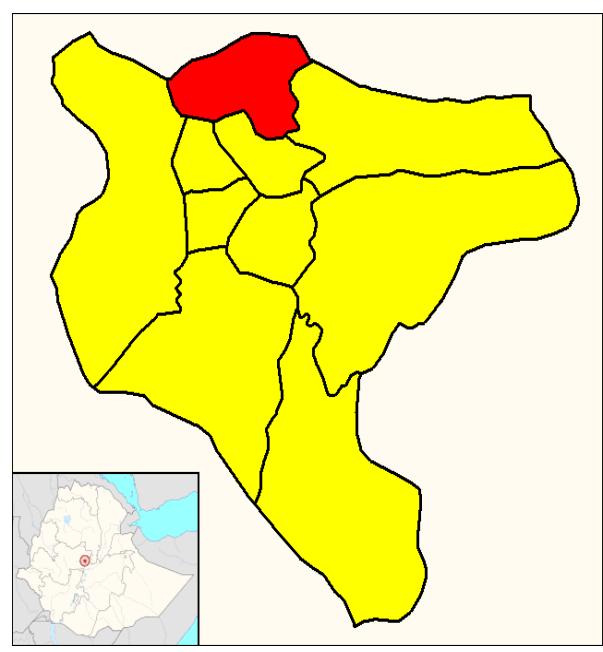

Figure 1. Map of the district (sub city) of Gulelle (shown in red) within the city of Addis Ababa (yellow)

\subsection{Research Design, Methods and Procedures}

Mixed concurrent triangulation research design was applied. Purposive sampling techniques was employed to select study sites (Gulelle sub-city Woreda 3, kebele 14) and to select sample households. Both primary source and secondary data sources were used. The study is based on cross-sectional survey of 50 household, purposely selected. Questionnaire survey, key informants interview and observations are the main tools for data collection.

Both qualitative and quantitative methods of data analysis were considered. Qualitative data played supplementary role and content analysis of the ideas, opinion, and concepts of data was considered. Nonetheless, for quantitative analysis of data SPSS Version 20 and STATA 14 were applied. Data was analyzed by various descriptive statistics. Contingent valuation method was employed to elicit household's willingness to pay for the proposed improvement in solid waste management service. The data from CVM survey was analyzed by using econometric model logistic regression.

\section{Model Specification}

Following the concept of the model from (7) the logit model for determinants of household's willingness to pay can be specified as below:

$$
\begin{gathered}
P^{(Y i=1)}=\frac{1}{1+e^{-(\beta \text { iXi })}} \\
P(Y i=1)=\frac{1}{1+e^{-(Z \mathrm{i})}}
\end{gathered}
$$

Where: $\mathrm{P}(\mathrm{Yi}=1)$ is the probability that a household is willing to pay, $\mathrm{Zi}=$ the function of a vector of explanatory variables), e- represents the base of natural logarithms and equation (2) is the cumulative distribution function. If $\mathbf{P}$ $(\mathrm{Yi}=1)$ is the probability of households willing to pay, then 1- $\mathrm{P}(\mathrm{Yi}=1)$ represents the probability that the household is not willing to pay and is expressed as: 


$$
\begin{gathered}
1-P(Y i=1)=1-\frac{1}{1+e^{-Z i}}=\frac{1}{1+e^{\mathrm{Zi}}} \\
\frac{P(Y i=1)}{1-(Y i=1)}=\frac{1+e^{\mathrm{Zi}}}{1+e^{-Z i}}=e^{Z i}
\end{gathered}
$$

Equation (4) simply is the odds ratio, the ratio of the probability that a household willing to pay to the probability that household is not willing to pay. Taking the natural log of equation (4), we obtain.

$$
L i=\operatorname{In}\left(\frac{P(Y i=1)}{1-(Y i=1)}\right)=Z i
$$

Where: $L_{i}$ is the log of the odd ratio which is not only linear in the explanatory variables but in the parameters also. Thus, introducing the stochastic error term $\left(u_{i}\right)$, the logit model can be written as

$$
Z_{i}=\beta_{0}+\beta_{1} X_{1}+\beta_{2} X_{2}+---+B_{n} X_{i}+u_{i-}
$$

Where $\mathrm{X}^{\prime} \mathrm{s}=$ are explanatory variables that determines the household willingness to pay.

$\beta_{o}$ is the constant term and $\beta$ 's are coefficients to be

\begin{tabular}{|c|c|}
\hline Variables & Variable definitions \\
\hline House Hold Id & Continuous variable \\
\hline Age & Continuous variable \\
\hline Sex & $\begin{array}{c}\text { Dummy variable which takes } 0 \text { if male and } 1 \\
\text { if female }\end{array}$ \\
\hline Education Status & $\begin{array}{l}\text { Categorical which takes } 0 \text { if illiterate, } 1 \text { if } \\
\text { elementary, } 2 \text { if high school, } 3 \text { if diploma, } 4 \\
\text { if degree and } 5 \text { if above degree }\end{array}$ \\
\hline $\begin{array}{l}\text { Period stayed at } \\
\text { sub-city }\end{array}$ & Continuous variable \\
\hline Household income & Continuous variable \\
\hline Household Size & Continuous variable \\
\hline $\begin{array}{l}\text { Solid waste } \\
\text { observation }\end{array}$ & $\begin{array}{l}\text { Dummy variable which takes } 0 \text { if Yes } \\
\text { (respondents observes wastes) and } 1 \text { if No } \\
\text { (respondents do not observe waste) }\end{array}$ \\
\hline $\begin{array}{l}\text { Frequency of } \\
\text { collections }\end{array}$ & $\begin{array}{c}\text { Categorical which takes } 0 \text { if No, } 1 \text { if once a } \\
\text { week, } 2 \text { if twice a week, } 3 \text { if three times and } \\
\text { above a week and } 4 \text { if every day }\end{array}$ \\
\hline $\begin{array}{l}\text { Evaluation of waste } \\
\text { problems }\end{array}$ & $\begin{array}{c}\text { Categorical which takes } 0 \text { if Very high, } 1 \text { if } \\
\text { High, } 2 \text { if Moderate, } 3 \text { if Little and } 4 \text { if No } \\
\text { problem }\end{array}$ \\
\hline $\begin{array}{l}\text { Evaluation of } \\
\text { efforts of } \\
\text { municipality }\end{array}$ & $\begin{array}{l}\text { Categorical which takes } 0 \text { if Very good, } 1 \text { if } \\
\text { Good } 2 \text { if fair, } 3 \text { if poor and } 4 \text { if very poor }\end{array}$ \\
\hline $\begin{array}{l}\text { Efficiency of } \\
\text { municipality } \\
\text { services }\end{array}$ & $\begin{array}{c}\text { Categorical which takes } 0 \text { if highly efficient, } \\
1 \text { if efficient, } 2 \text { if moderate, } 3 \text { if Inefficient } \\
\text { and } 4 \text { if Highly inefficient }\end{array}$ \\
\hline Willingness to pay & $\begin{array}{c}\text { Dummy variable which takes } 0 \text { if yes and } 1 \\
\text { if No }\end{array}$ \\
\hline $\begin{array}{l}\text { How much } \\
\text { Willingness to pay }\end{array}$ & $\begin{array}{c}\text { Categorical which takes } 0 \text { if Less than Birr 5, } \\
1 \text { if } 10 \text { birr, } 2 \text { if } 15 \text { birr, } 3 \text { if } 20 \text { birr, } 4 \text { if } 25 \text { birr } \\
\text { and } 5 \text { if } 30 \text { birr }\end{array}$ \\
\hline $\begin{array}{l}\text { Maximum } \\
\text { Willingness to pay }\end{array}$ & Continuous variable \\
\hline
\end{tabular}
estimated.

Variable Definitions

Table 1. Variables definitions

\section{Results and Discussion}

\subsection{Descriptive Statistics}

Majority of the respondents (96\%) are found between the age group of 15 and 65 . The remaining $4 \%$ of the respondent constitute the age group above 65 . Regarding the gender of participants, $58 \%$ and $42 \%$ participants are male and female respectively. Concerning the educational status of the respondents, the majority of the respondent's (64\%) had undergraduate degree. The remaining $8 \%, 10 \%$ and $16 \%$ are elementary, secondary school student and diploma holders respectively. Majority of households (48\%) earns more than 3000 birr per month which is followed by 1000 to 2000 birr per month (28\%) and 20001 to $3000(20 \%)$ respectively. Only few of them (4\%) earns less than 1000 birr per month. With reference to household size, most of the respondent $(66 \%)$ had family below five. The remaining $24 \%$ and $10 \%$ of the respondents has the household size of 5 to 8 and above eight respectively. Finally, most of the respondent's (64\%) have lived in the sub-city for less than 10 years. In addition, $14 \%$ of households lived in sub-city for 10-20 years and only few $(10 \%)$ of them lived for 40 years in sub-city.

\subsection{Household's Willingness to Pay for Improved SWM Service}

The Willingness to pay was estimated using STATA version 14 to determine the relationship between WTP, dependent variable, and each of the independent variables.

\subsubsection{The Maximum Willingness to Pay}

Households were also asked to state their maximum willingness to pay for the improved solid waste management. The survey result shows that different maximum willingness to pay values is reported if the proposed improved solid waste management service is implemented.

As indicated in table 2 below, out of the total sample surveyed households, about $22 \%$ of them were willing to pay less than five Birr while a quarter of them were willingness to 10 birr per month. About 24\%, 10\% and $14 \%$ of the respondents were willing to pay per month for the improved SWM. Accordingly, 22\% (11) of the respondents were willing to pay a maximum of 5 and 10 Birr per month for the proposed SWM services respectively. Whereas, almost $28 \%$ (14) households are willing to pay 20 Birr at maximum, $7(14 \%)$ of the respondents expressed their maximum willingness to pay to be 30 Birr per month and finally, almost $5(10 \%)$ of the sampled households became willing to pay 45 Birr and above of improved SWM. 
Table 2. Summary of Maximum Willingness to Pay

\begin{tabular}{cc}
\hline $\begin{array}{c}\text { Reported Maximum WTP for Improved } \\
\text { SWM (Birr) }\end{array}$ & $\begin{array}{c}\text { Frequency } \\
\text { (Percent) }\end{array}$ \\
\hline Less than 5 birr & $11(22)$ \\
10 Birr & $15(30)$ \\
15 Birr & $12(24)$ \\
20 Birr & $2(4)$ \\
25 Birr & $3(6)$ \\
30 Birr & $7(14)$ \\
\hline
\end{tabular}

Source: Own field survey, 2017

\subsubsection{Correlation Analysis between Household WTP and Independent Variables}

The result of correlation matrix between the WTP (continuous dependent variable) and the independent variables indicates that the majority of the exogeneous variables, except the household size, were insignificant in explaining the household's willingness to pay for improved SWM services in Gulele Sub-city Woreda 3. Specifically, the age, income, period stay and household size of the household head respectively were positively correlated with household's WTP for the proposed improvement in SWM whereas sex and education level of the respondents were negatively correlated with WTP for the proposed improvement in SWM services in Gulele Sub-city Woreda 3 , though they were insignificant.

As indicated in table 3, the correlation between exogenous variables and the dependent variable (WTP for Improved SWM service) was very small, less than 0.5 , or statistically insignificant.

Table 3. Correlations of Major Variables

\begin{tabular}{cc}
\hline Independent Variables & Monthly WTP \\
\hline Age of Household & $0.2351(0.1003)$ \\
Sex of Household & $-0.0038(0.9791)$ \\
Education Status of the Household & $-0.1927(0.1799)$ \\
Household Income & $0.0962(0.5064)$ \\
Household size & $0.4110(0.0030) *$ \\
Period of Stay & $0.1324(0.3595)$ \\
\hline
\end{tabular}

* Significant at $1 \%$. The value in the bracket indicates significance level

\subsubsection{Empirical Results of Households Willingness to Pay}

A contingent valuation method was employed to elicit household's willingness to pay for the proposed improvement in solid waste management services in Gulele Sub-City, Wereda 3, Addis Ababa, Ethiopia. The Study was based on cross-sectional survey of 50 households selected purposively. Out of the total 50 respondents that were questioned on their willingness to pay to improve solid waste management, about 76 percent of the households had a positive willing to pay values for improvement in solid waste management starting from 5 Birr per month while the rest, 24 percent, were not willing to pay. The percentage of positive WTP values was compatible with the findings of the previous studies in many parts of the developing world including Ethiopia. For instance, according to the study conducted in Addis Ababa, a higher percentage (90\%) of positive WTP resulted in an improved waste collection service (6). Likewise, also showed that a higher number $(80 \%)$ of households in Gujranwala, Pakistan were willing to pay for an improved waste collection service. Furthermore, a similar study carried out in Kathmandu, Nepal obtained $80 \%$ of household's WTP for an improved service. In general, this tells us that if more firms that are private are involved in the provision of an improved solid waste management service large number of Addis Ababa residents might be willing to pay for the service.

The mean monthly willingness to pay amount is $21 \mathrm{Birr}$ with a minimum of 5 Birr and the maximum of 100 Birr. The standard deviation of for the maximum willingness to pay amount is 20.88. Table 3 provides WTP responses in relation to the socioeconomic characteristic of the sample households.

\subsubsection{Determinants of Household Willingness to Pay}

To identify the factors influencing WTP for improved SWM services, the household responses to the WTP question was regressed against socioeconomic characteristics of the households and the results reported in table 4 below. The study revealed that the majority of the respondents were willing to pay for alternative waste disposal services, particularly when it is going to be an improvement on the existing means of services.

Nonetheless, as presented in table 4, many variables in this logit model turned out insignificant because of the small sample we selected due to resource constraints both time and budget.

Table 4. Logistic Regression Results on Determinants of Household WTP for Improved SWM Services

\begin{tabular}{cccc}
\hline $\begin{array}{c}\text { Explanatory } \\
\text { Variables }\end{array}$ & Coefficient & $\begin{array}{c}\text { Stand. } \\
\text { Error }\end{array}$ & P-values \\
\hline Constant & -1.0512 & 2.986513 & 0.725 \\
Age & -.0094 & .0417 & 0.823 \\
Sex & $-3.0755^{*}$ & 1.48864 & 0.039 \\
Education Level & -.0862 & .7166539 & 0.229 \\
HH Income & .0004 & .0003046 & 0.191 \\
HH Size & $.6102 * *$ & .2312326 & 0.008 \\
\hline
\end{tabular}

** significant at $1 \%$ * significant at $5 \%$

Source: Own field survey, 2017

Pseudo $\mathrm{R}^{2}$ value is 0.28 , which means that about 28 percent of the variables in WTP are explained by the included independent variables and the remaining 72 percent is unexplained. The value of $\mathrm{R}^{2}$ for our logistic regression model is 0.28 , according to (9) is quite acceptable, because that regressions on CV data usually yield $\mathrm{R}^{2}$ values between $10 \%$ and $40 \%$.

We hypothesized that age of respondent, sex of the 
respondent, household size, level of education and respondent's household income are the factors affecting willingness to pay for improved solid waste management. However, evidence from the logit model indicated that only two variables had significant influence on the households' willingness-to-pay namely household size and gender of the respondents.

Table 4 above, presents the logit analysis of the factors that influences the willingness to pay for improved waste disposal services. The results of logit regression analysis showed that respondents' age, education level, and household income do not significantly influence the willingness to pay for improved waste disposal. However, sex and household size are statistically significant at $\mathrm{P}<$ 0.05 and $\mathrm{P}<0.1$ respectively.

The likelihood ratio chi-square of Prob $>$ chi2 $=-19.96$ with a p-value of 0.0096 tells us that our model as a whole fits significantly better than an empty model i.e., a model with no predictors. As one unit increase in age, sex and education level of the respondents, the odds of household WTP for improved SWM decreases by $0.99,0.05$, and 0.42 respectively.

For every one unit change in age, the log odds of WTP for the improved SWM decreases 0.0094 and for every one unit change in sex, the log odds of WTP for the improved SWM decreases by 3.0755 and 0.0862 for education level. On the contrary, for each unit change in household income and household size the logs odd of WTP for the improved SWM increases.

\section{Household Income}

Household income is the amount a household earns on monthly basis and the higher the income the more willing individual are to manage their waste through the payment fee system. It was hypothesized that level of education had a negative effect on household solid waste disposal in open areas, along the roads but a positive effect on solid waste recycling and reuse. Households with high education levels were expected to reduce unauthorized waste disposal and increase waste reuse and recycling.

Generally, there is a general agreement in the environmental economics literature on the positive relationship between income of the head of the household from all sources and demand for improvement in environmental quality (10). Therefore, we expect the income to affect the willingness to pay and its amount positively. However, due to the smaller the sample, the result for income variable was insignificant at $1 \%, 5 \%$ and $10 \%$.

\section{Age}

It is expected that older citizens are more mature decisions related to evaluating health and environmental issues, possibly due to their age, leading them to express high willingness to pay value. However, the result from logit regression was indicated that the coefficients on age variables are statistically insignificant at either the $10 \%$ level or $5 \%$ level or $1 \%$ level with negative sign. The negative sign shows that the probability of WTP 'yes' is likely to be higher in younger respondents than in older one. The sign shows that as the age of the household head goes up, the probability of WTP decreases which is contrary to our hypothesis of positive relationship with households WTP. The result of logistic regression in table 3 above reveals that for every one-unit change in age, the log odds of WTP for the improved SWM service decreases by 0.0094 .

\section{Education Level of the Respondent}

The education level of the respondent is taken to capture the number of years the respondent spent informal school system. Similar to the age variable, Education level of the household head is expected to have positive and significant effect on waste management and strong positive relationship with amount of WTP. Obviously, it is believed that as the education level increases so is the capacity of the people to become more knowledgeable on SWM and hence becoming more willing to pay for improved SWM. The study made by on determinants of willingness to pay for improved household solid waste management in Kampala City confirms the same conclusion, which also indicates that education of households has a positive effect to willingness to pay for improved solid waste management among households.

Surprisingly, however, the level of education in our study is not statistically significant at $1 \%, 5 \%$ and $10 \%$ respectively. In some contingent valuation studies, depending on the good under evaluation, a more educated population is on average more likely to be willing to pay for public goods $(12,13)$. The result from logit regression in our study was statistically insignificant may be due to the small sample we selected. The other reasons for the lack of significance of education level in the participation equation can be easily explained by noting that our sample did not target household head with different educational attainments. However, it is logical that as respondent's educational level increases, their income increases this leads to increase environmental demand. Thus, the longer period the individual spent in formal school system, the more likely that he/she would be willing to pay more for improved waste management.

The logistic regression output in our study shows that respondents with higher education have no significant difference in paying to improved SWM. This result is similar with the study made by the research finding in Ethiopia, which pointed out, that the education level of the respondents does not have a significant impact on the demand for improved services of waste collection.

\section{Household Size}

The number of household members could have an expected positive or negative influence on the willingness 
to pay because the more children in the household, the more they would prefer to use their children to clean the environment than paying more to the municipal authorities to clean the environment. Furthermore, it is expected that large size families generate large amount of solid waste. Therefore, households with large family sizes are likely to support improved SWM than the household with smaller family size. As expected, this variable is significant at $1 \%$ significant level. However, the more number of people in the household, the more the waste generated, hence disposal becomes a problem, therefore it expected to be more willing to pay in order to keep a clean environment.

Contrary to our result, a study conducted by in Bahir Dar, Ethiopia shows that household WTP is affected by level of education, family size, number of children, years of stay and income of the household. However, family size is inversely related with the probability of saying yes to the WTP.

\section{Conclusions}

The Study was based on cross-sectional survey of 50 households selected purposively. Out of the total 50 respondents that were questioned on their willingness to pay to improve solid waste management, about 76 percent of the households had a positive willing to pay values for improvement in solid waste management starting from 5 Birr per month while the rest, 24 percent, were not willing to pay. The percentage of positive WTP values was compatible with the findings of the previous studies in many parts of the developing world including Ethiopia. This tells us that if more firms that are private are involved in the provision of an improved solid waste management service large number of Addis Ababa residents might be willing to pay for the service.

The study used the CVM to elicit households' willingness to pay for improved solid waste management in Gulelle Sub-City Woreda 3 area. A logit regression model was then estimated to investigate the factors influencing households' willingness to pay. The logit model shows that the WTP amount is affected by various socioeconomic factors. Based on the findings of the study, it can be concluded that family size and gender of the respondents were significant factors in influencing people's willingness to pay for improved SWM service in Gulelle Sub-City at 1\% and 5\% respectively. Age, education level and income of the household head were found to be insignificant factors in influencing people's willingness to pay for improved SWM in the study area contrary to our hypothesis. The likelihood ratio chi-square with a p-value of 0.0096 indicates that our model as a whole fits significantly better than a model with no predictors. The result of correlation matrix between the WTP and the independent variables indicates that the majority of the exogenous variables, except the household size, were insignificant in explaining the household's willingness to pay for improved SWM services.

Addis Ababa municipality should take the initiatives of establishing sanitary landfills, and encourage establishment of private service provider (solid waste contractors) to improve the solid waste collection in the city by increasing trucks and collection frequency per week. The study recommends that entrepreneurs and innovators should be encouraged to develop improved schemes for waste collection and management.

\section{Acknowledgements}

First and more most, let immeasurable thanks goes to Almighty God for his invaluable gifts, endowed in us skills and ability to handle things, keep us stay in peace and health. Next, we are very much grateful to our professors for giving us this research work. In addition, we have enormously benefited from deep knowledge of households and our key informants. All of them shared us their knowledge and experiences with patience without the feeling of tiredness. Meticulous discussion with participants is unforgettable.

\section{Authors' Contributions}

All authors conducted the field research and analyzed the data. All authors designed the research, and interpreted the results. However, Galgalo Dika has prepared and revised the manuscript.

\section{Conflicts of Interest}

The authors declare that they have no conflicts of interests.

\section{REFERENCES}

[1] Birhanu, Berisa. Assessment of Solid Waste Management Practices and the Role of Public Participation in Jigjiga Town Somali Regional State, Ethiopia. International Journal of Environmental Protection and Policy. 2015; 3(5): p. 153-168.

[2] Regassa N, Sundaraa D, Seboka B. Challenges and Opportunities in Municipal Solid Waste Management: The Case of Addis Ababa City, Central Ethiopia. Human Ecology. 2011: p. 179-190.

[3] Koyachew EK. The Problem of solid waste management and people awareness on appropriate Solid Waste Disposal in Bahir Dar City, Amhara Reion, Ethiopia. Journal of health and environmental science. 2016.

[4] Matthew. Environmental Policy Review 2011: Waste 
Management in Ethiopia. 2011.

[5] Schleicher T, Manhart A, Amera T, Belay A, Zamanu G. An efficient \& effective e-waste collection system for Ethiopia. 2015 ..

[6] Amiga A. Household's willingness to pay for improved solid waste management: The case of Addis Ababa. 2002 June.

[7] Gujarati DN, Porter DC. Basic Econometrics. 5th ed. New York: McGraw-Hill; 2009.

[8] Altaf MA, Deshazo JR. Demand for Improved Solid Waste Management: A Case Study of Gujranwala. World Development. 1996; 24(5): p. 857-868.

[9] Mitchell R, Carson R. Using surveys to value public goods: The Contingent Valuation Method Baltimore: Hobkins Press; 1989.

[10] Awunyo-Vitor D, Ishak S, Seidu J. Urban Households Willingness to Pay for Improved Solid Waste Disposal Servicesin Kumasi Metropolis, Ghana. 2013.

[11] Niringiye A, Omortor G. Determinants of Willingness to Pay for Solid Waste Management in Kampala City. Research Journal of Economis Theory. 2010; 2(3): p. 119-122.

[12] Thompson E, Berger M, Blomquist G, Allen S. Valuing the Arts: a Contingent Valuation Approach. Journal of Cultural Economics. 2002; 26(2): p. 87-113.

[13] Amirnejad H, Khalilian S, Assareh MH, Ahmadian M. Estimating the Existence Value of North Forests of Iran by Using a Contingent Valuation Method. Ecological Economics. 2006; 58(8): p. 665-675.

[14] Tewodros T, Samson H. Demands for Improved Solid Waste Collection Services: A Survey in Mekelle City. Journal of the Drylands. 2009; 2(1): p. 32-39.

[15] Birtukan BW. Households Demand for Improved Solid Waste Management Service in Ethiopia: the case of Bahir Dar City. In Proceeding of ninth International Conference on the Ethiopian Economy; 2013: Ethiopian Economic Association. 